Historic, archived document

Do not assume content reflects current scientific knowledge, policies, or practices. 



\section{AND HARDWOODS}

CONVERTING BRUSH

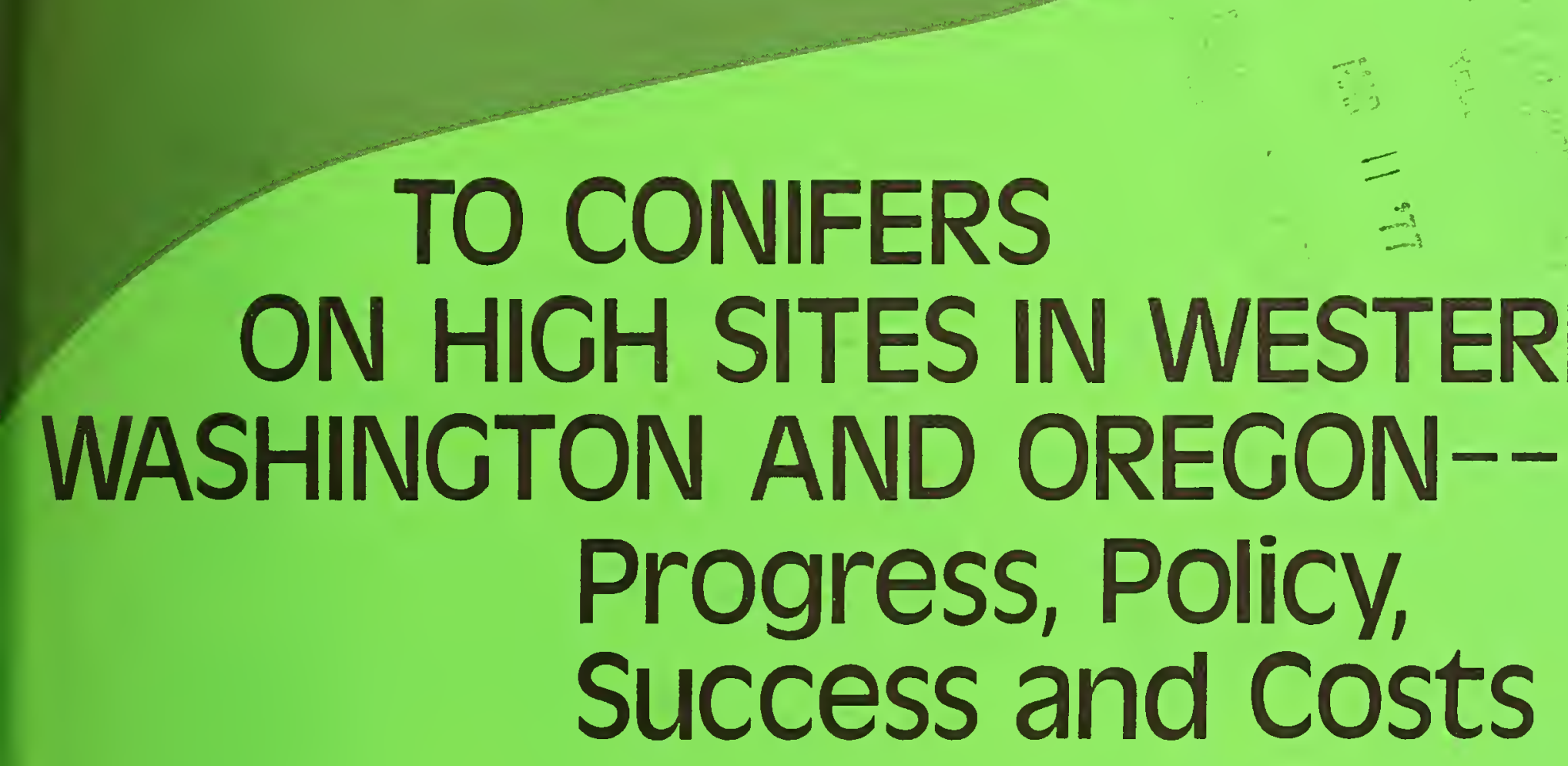

\section{Edward J. Dimock II Enoch Bell Robert M. Randall}





\title{
Converting Brush and Hardwoods to Conifers on High Sites in Western Washington and Oregon-- Progress, Policy, Success and Costs
}

\author{
Reference Abstract \\ Dimock, Edward J. II, Enoch Be11, and Robert M. Randa11 \\ 1976. Converting brush and hardwoods to conifers on high sites \\ in western Washington and Oregon--Progress, policy, success \\ and costs. USDA For. Serv. Res. Pap. PNW-213, 16 p., illus. \\ Pac. Northwest Forest and Range Experiment Station, \\ Portland, Oregon.
}

\begin{abstract}
Evaluates opportunities, techniques, success and cost of brushland reclamation efforts for almost a 20-year period. Among newer techniques, slash-and-burn and spray-and-burn are consistently more successful--and more economical per established conifer--than multiplespray conversions.
\end{abstract}

KEYWORDS: Type conversion (forest), conversion (silvicultural)

-)planning, reclamation (forest land), regeneration

(stand), hardwoods, softwoods.

\section{RESEARCH SUMMARY}

Research Paper PNW-213

1976

Over 6.1 million acres of forest lands were surveyed in 1975 to evaluate status of brushland reclamation on ownerships managing commercial timber. These lands currently sustain 110,000 acres of brush and 757,000 acres of brushhardwood mixtures growing on highly productive sites. Nearly all the former and about 88 percent of the latter are scheduled for eventual type conversion to higher-yielding conifers. The balance will be retained in hardwoods for either timber production or environmental protection.

During the past 20 years, 216,000 acres have already been converted to conifers by a variety of methods. Tractor scarification--with or without utilization of merchantable trees--has been the commonest reclamation technique and was used on over half the total area converted. Harvesting merchantable timber--with only incidental site preparation--was the method employed on another 23 percent of the total reclaimed. The remaining 22 percent was converted by more recently developed techniques: multiple spray, slash and burn, spray and burn, and high-lead scarify.

Success varied with all methods. Best, and least variable, results were attained on spray-and-burn and slash-and-burn conversions that generally produced good stocking and high tree density at moderately high cost. Multiple-spray conversions were, neaper on an area basis, but gave generally poorest results at more than double the cost per established conifer. Harvest-only and tractorscarify methods were least expensive, but are best suited to easiest conversion opportunities that are becoming decreasingly common. Methods combining chemicals and fire tentatively appear to have greatest potential for future use and further development in brushland reclamation. 



\section{Contents}

Page

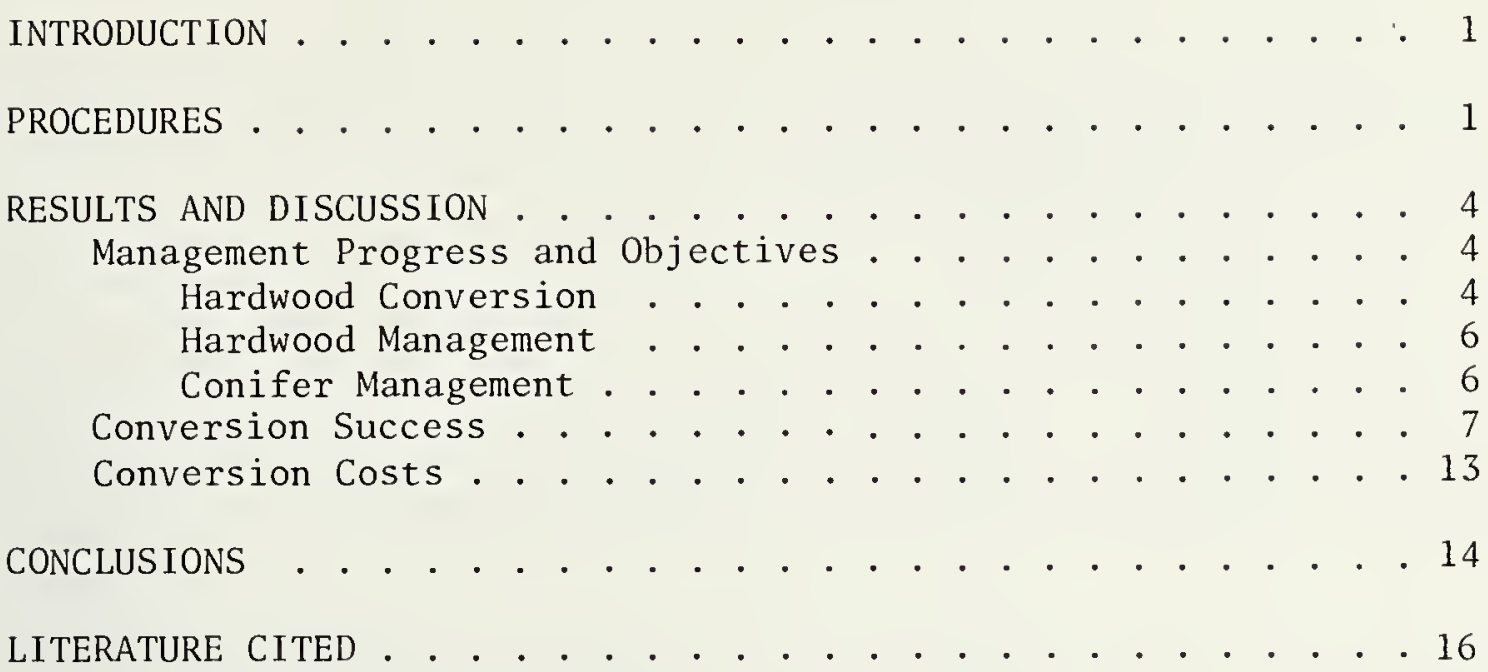

This publication reports research involving pesticides. It does not contain recommendations for their use, nor does it imply that the uses discussed here have been registered. All uses of pesticides must be registered by appropriate State and/or Federal agencies before they can be recommended.

CAUTION: Pesticides can be injurious to humans, domestic animals, desirable plants, and fish or other wildlife -- if they are not handled or applied properly. Use all pesticides selectively and carefully. Follow recommended practices for the disposal of surplus pesticides and pesticide containers.

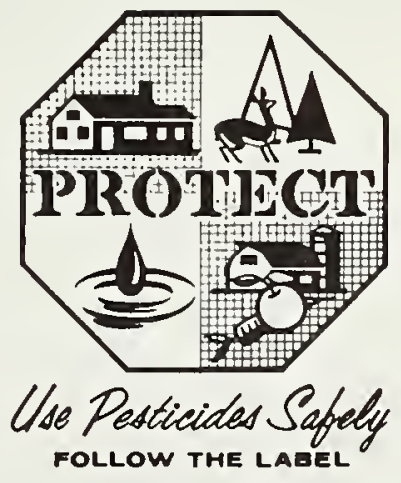

U.S. DEPARTMENT OF AGRICULTURE 



\section{Introduction}

Rehabilitation of high-site forest lands in the Pacific Northwest currently lags far behind the need. About 2.4 million acres, potentially capable of supporting valuable stands of Douglas-fir (Pseudotsuga menziesii) and other conifers in the Oregon-Washington Coast Ranges and the Cascade Range foothills of Washington, presently sustain plant communities of low commercial value (Gratkowski et al. 1973). These comprise either brush or brush-hardwood mixtures that are nonstocked or poorly stocked with conifers. Some of these lands are best suited to continuing production of hardwoods--but most low-value hardwood stands should be converted to more productive conifers. For the most part, these plant communities are seral stages that will eventually be replaced by climax forests typical of the Tsuga heterophyzla and Pi.cea sitchensis zones as described by Franklin and Dyrness (1973). Silvicultural methods to reclaim these lands are now available.

Brushland reclamation is neither easy nor cheap and has only been pursued actively in the Pacific Northwest since the mid-1950's. However, increasing timber and land values have spurred increasing interest in converting brush and hardwoods to conifers. High quality sites command first priority but usually present problems of greatest difficulty. Resprouting shrubs, fast-growing hardwoods, and conifer-damaging animals combine to impede conversion attempts. Existing conversion techniques involve combinations of harvesting, scarifying, slashing, burning, herbicide spraying, animal control, and artificial regeneration. These techniques vary in effectiveness and intensiveness. No technique is a panacea, but all can succeed under given circumstances. Assessment of current practices and the situations to which they best apply are therefore urgent needs.

A survey was conducted during the summer of 1975 to evaluate economic aspects of hardwood management and brushland conversion. This paper summarizes results of that survey as they pertain to various conversion practices and their relative success in the Oregon-Washington Coast Ranges and Washington Cascade foothills.

\section{Procedures}

We obtained data in two ways: (1) by interviewing cooperating 1 and management organizations, and (2) by examining selected conversion projects in the field.

Initially, the two-State region previously described was subdivided into eight zones containing high-site brush and hardwood (chiefly red alder (AInus rubra)) reclamation opportunities: Washington Coastal Plain, North Cascade Foothills, Willapa Hills, South Cascade Foothills, Nehalem Hills, Tillamook, Oregon Coastal plain, and Oregon Coast Range (fig. 1). We selected 16 organizational units, representing eight industrial timber ownerships and three public land management agencies. These cooperators agreed to provide general information on brushland management for their holdings and detailed data on specific reclamation projects. Organizational units were evenly distributed (eight each) between 


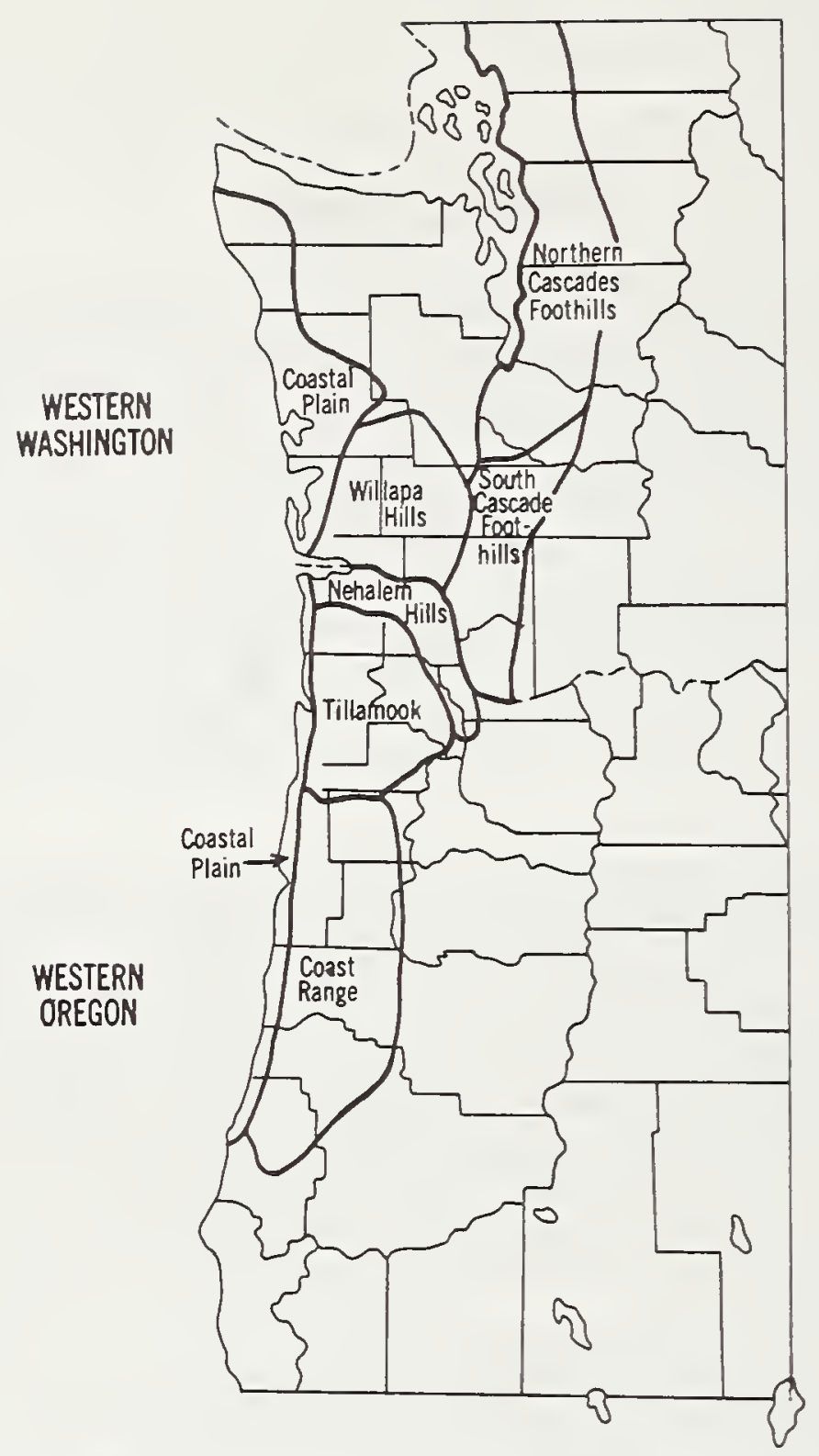

Figure 1.--High-site brush and hardwood reclamation zones surveyed in western Washington and Oregon.

Washington and Oregon. Cooperators were selected on the basis of geographic area and demonstrated experience and familiarity with various conversion practices. Though the ownership sample was not random, it should provide a fairly representative picture of brush conversion and hardwood management practices as they now exist throughout the designated reclamation zones.

Conversion techniques employed by each organizational unit were grouped into six categories by total area treated to date:

1. Hamest only - - removal of merchantable overstory with only incidental site preparation and slash disposal.

2. Tractor scarify -- partial or complete disruption of slash and shrub residues remaining after harvest; or crushing and uprooting of shrubs and unmerchantable hardwoods without harvest; residues usually windrowed, burned, or both. 
3. Multiple spray -- application of one or more herbicidal sprays to young hardwoods and tall brush immediately before and after planting large conifer stock.

4. Slash and burn -- felling all live and dead hardwoods; understory shrubs usually desiccated with herbicides and broadcast burned by mass ignition.

5. Spray and burn -- herbicidal treatment of standing unmerchantable hardwoods and brush, without slashing, followed by broadcast burning; most often applied in low brush shortly after harvesting merchantable overstory.

6. High-lead scarify -- crushing and uprooting brush and unmerchantable hardwoods by cable yarding with heavy weights.

Nearly all techniques were accompanied by hand planting--sometimes supplemented by seeding. Relatively few managers relied on artificial seeding as the sole regeneration method. Where two or more conversion techniques overlapped, the one deemed to have had the greatest impact was used to categorize the method.

Projects of "average" effectiveness wel selected to avoid sampling either outstanding successes or failures. Projects initiated before 1957 or after 1971 were generally excluded to avoid those too old to provide relevant data or too recent to provide a fair measure of their effectiveness. Each conversion method was sampled approximately in proportion to the commonness of its use within a given organizational unit. Occasional departures from this last guideline were made to favor selection of projects employing more recent technology.

For each conversion project sampled, we recorded the per-acre costs and dates of occurrence for all stand establishment activities and silvicultural treatments from the start of the conversion to the end of the regeneration period. Costs came from actual records, but sometimes only estimates were available. We included costs associated with release spraying but excluded those such as precommercial thinning and fertilizing which are aimed at stand culture rather than stand establishment. We adjusted each cost by a factor derived from the U.S. Gross National Product deflator--with 1975 chosen as the base year for comparison.

In the field, each project was described by general features of size, aspect, slope, site, overstory, and understory. Understories were assigned to one of four plant community classifications that might reflect relationships between plant communities and conversion success. Classifications were: (1) sword-fern (Polystichum munitum), (2) salmonberry (Rubus spectabilis), (3) vine maple (Acer circinatum), and (4) salal (Gaultheria shazlon). Projects ranged from 18 to 762 acres, and several types of understory were commonly present on any given site. Assignment of a single classification to each project was therefore judgmental and necessarily subjective.

Conversion success was determined by regeneration surveys to assess the distribution, composition, age, height, and number of established conifers. A transect of 25 sampling points provided stocking and density estimates for each project regardless of its size. Estimates of stocking (in percent) were by the stocked-quadrat method based on $1001 / 250$ th-acre plots per project; estimates of density (in trees/acre) by the distance method based on 25 sampling points per project. 
Transect lines were systematically spaced throughout each project area to generate average estimates from a wide range of conditions. At each sampling point, four $1 / 250$ th-acre plots were laid out as four sectors of a 14.9-foot radius circle. On each sector, the tallest established conifer, its species, age from seed, and estimated height were noted. Only trees at least 3 years old were considered established. In addition, the distance from each sampling point to the closest established conifer was measured to the nearest $1 / 10$ th foot.

\section{Results and Discussion}

\section{MANAGEMENT PROGRESS AND OBJECTIVES}

Organizations sampled own or manage over 6.1 million acres of forest land in the brush and hardwood reclamation zones previously described (table 1). Of this area, 60 percent lies in Washington and 40 percent in Oregon; 38 percent is under State and Federal management and 62 percent in industrial holdings.

About 14 percent, or 867 thousand acres, of this collective ownership are dominated by brush and hardwoods, mostly suitable for conversion to conifers. Within the confines of this sample, Washington contains slightly more potentially convertible lands (55 percent) than Oregon (45 percent). Public and private conversion opportunities are split about equally (52 percent versus 48 percent).

Of the above acreage, 87 percent is classed as hardwood (i.e., containing over 30 percent stocking in hardwood species). The balance (13 percent) consists chiefly of brush with a negligible component of hardwoods.

\section{HARDWOOD CONVERSION}

Substantial progress in converting brush and hardwoods has already been made. To date, nearly 216 thousand acres on the ownerships sampled have been converted. Most lands reclaimed previously are now satisfactorily stocked with conifers. The bulk (84 percent) lie in Washington and probably reflect logging histories and ownership patterns that generally differ from Oregon. The ratio of private to public lands converted--84 and 16 percent, respectively--also suggests somewhat differing management objectives between the two classes of ownerships.

Tractor scarification has been the dominant conversion technique used in both States for both private and public ownerships. Nearly 120 thousand acres, or 55 percent of the sampled conversion area, were treated by this method. Harvesting with little or no site preparation accounted for 23 percent of the acreage in older conversions and was normally applied in mature hardwood stands where problems with slash and brush were minimal. More recently developed methods are less well represented. Lands converted by these methods include: multiple spray, 9 percent; spray and burn, 7 percent; slash and burn, 5 percent; and high-lead scarification, 1 percent.

Of the 757 thousand acres now cli ssed as predominantly supporting hardwoods, 665 thousand acres ( 88 percent) are planned for eventual conversion to conifers by their managers. Based on the 16-unit sample, hardwood acreage remaining to be converted on public lands exceeds that on private holdings. Also, conversion opportunities remaining in Washington somewhat exceed those in Oregon. If areas 


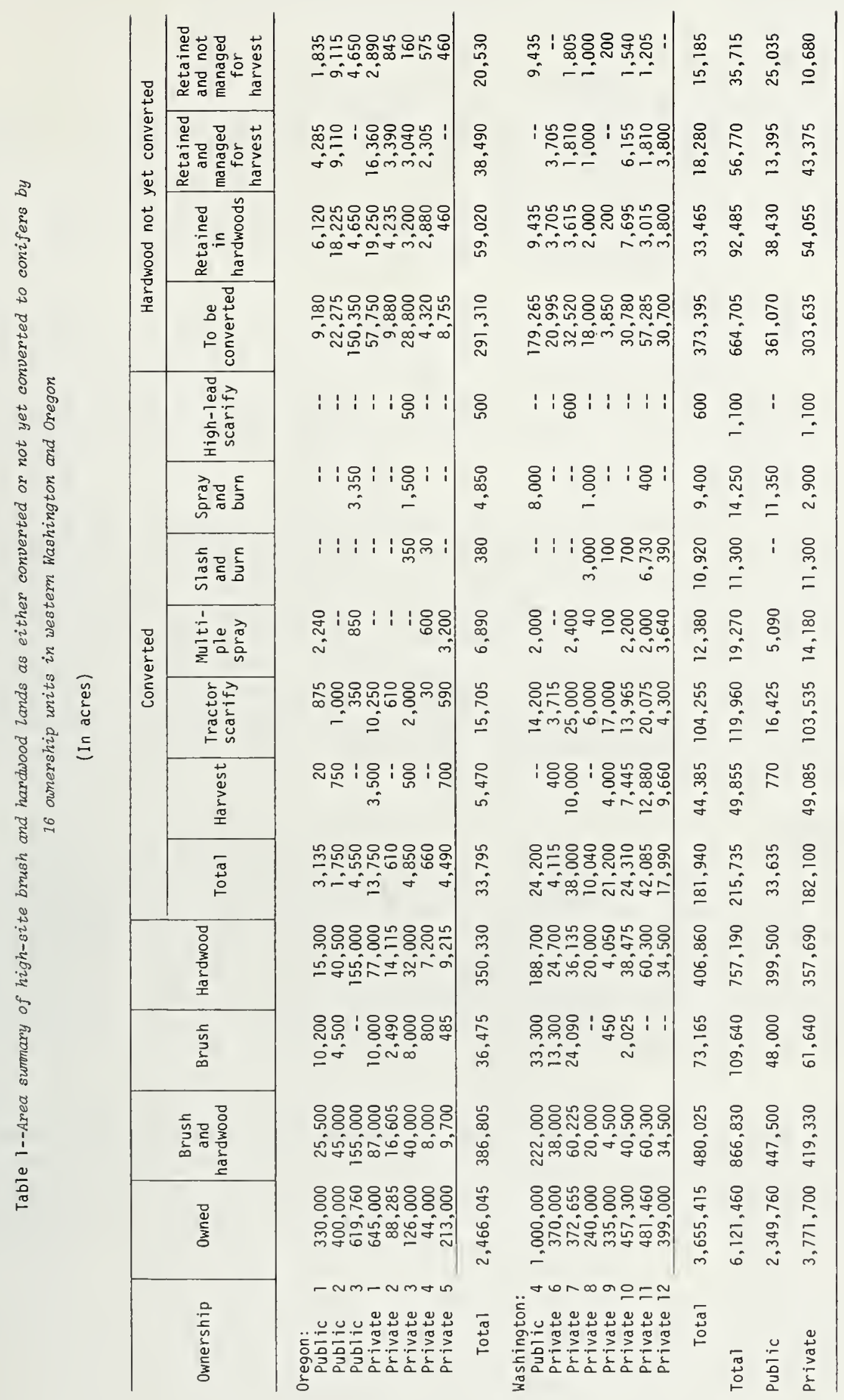


surveyed, however, are adjusted for the disproportionate land base represented in Oregon and Washington, conversion opportunities between the two States are probably about equal.

\section{HARDWOOD MANAGEMENT}

Retention of hardwood types is currently anticipated for over 92 thousand acres $v^{6} 12$ percent of the lands thus classified. Sixty-one percent of this acreage is to undergo some form of timber harvest with no attempt at type conversion. No timber harvesting is planned for the 36 thousand-acre balance chiefly retained as buffer strips for stream protection. Managers indicated legal, esthetic, and economic reasons for not converting these riparian sites to conifers.

By percentage of respondents, the following factors were cited in descending order of frequency as reasons for maintaining hardwood cover types: (1) sites unsuited to conifers (94 percent), (2) State water quality regulations (75 percent), (3) esthetic or recreational considerations (56 percent), (4) unfavorable financial analysis (44 percent), and (5) other reasons that included insufficient funding and manpower, amelioration of root rot problems, and preservation of wildlife habitat and hardwood supply (31 percent).

A generally low intensity of management is anticipated for the 57 thousand acres of hardwood types retained for sustained harvest. Simply waiting for natural hardwood regeneration after harvest is the commonest regeneration policy. A less frequently followed policy encourages natural hardwood regeneration with minimal site preparation. Only one respondent indicated a general policy of harvesting, site preparation, black cottonwood (Populus trichocarpa) planting, and thinning. Limited cottonwood planting was also anticipated by two other respondents, but not as a matter of general policy. Mean planned rotation length among all ownerships managing hardwood lands for a sustained yield of hardwood products (chiefly red alder) was 45 years.

\section{CONIFER MANAGEMENT}

In contrast to hardwood management policies, a generally high intensity of management is planned for conifer stands already converted from hardwoods and brushfields as well as for the two-thirds million acres scheduled for future conversion (table 2). Planting following site preparation is the almost universally preferred regeneration strategy. Only 19 percent of organizations contacted planned to conduct any artificial seeding on converted lands, and then only at minimal levels to supplement planting.

Although Douglas-fir remains the species of choice for conifer plantations, western hemlock and other conifers will be increasingly used by forest managers. Only 3 of 16 organizational units contacted plan to rely entirely on Douglas-fir. The balance anticipate planting at least 5 percent hemlock and other conifers. One fourth of all managers will use at least 20 percent hemlock and other conifers in their conversion programs, and one large owner will plant 75 percent hemlock.

A trend toward use of large planting stock in conversion projects is also nearly universal. Only 31 percent of the managers contacted planned to use any smal1, bare-root stock, and even those managers will use more large stock than small. Containerized planting stock will assume increasing importance, especially among those managers planning to regenerate with western hemlock and conifers 
Table 2--Regeneration and management strategies planned by 16 ownership units for converting high-site brush and hardwood zands to conifers in western Washington and oregon

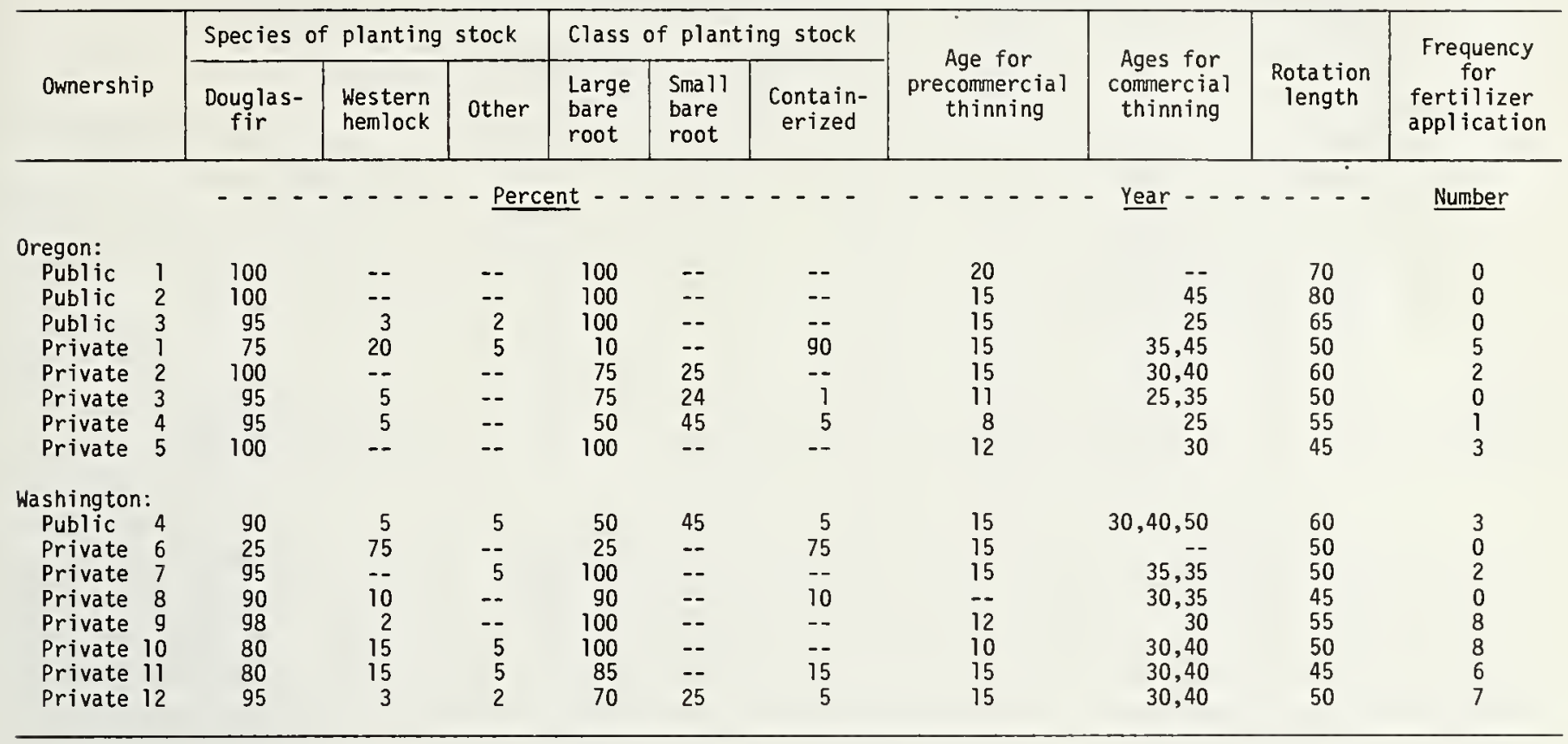

other than Douglas-fir. Half the sampled ownerships plan to use at least some container-grown stock, and two organizational units currently favor its use over bare-root seedlings.

All but one organization plan to thin converted stands precommercially at 8-20 years, most usually at age 15. All but two organizations intend to thin converted stands commercially--usually several times--before final harvest. Most private managers ( 75 percent) plan to fertilize their converted stands at time of precommercial thinning and at frequent intervals thereafter. Chiefly because of environmental restrictions, public land managers presently contemplate only limited forest fertilization in converted stands. Mean rotation length planned on private lands averages 50 years; on public ownerships just under 70 years.

\section{CONVERSION SUCCESS}

To evaluate success of the 6 conversion techniques previously defined, we examined 99 conversion projects. Projects were distributed among 8 designated conversion zones as follows: Washington Coastal Plain (9), Willapa Hills (10), North Cascade Foothills (14), South Cascade Foothills (21), Nehalem Hills (9), Tillamook (12), Oregon Coastal Plain (3), and Oregon Coast Range (21). Sampling of conversion techniques was roughly in proportion to past use of the method (table 1): 


\begin{tabular}{lcc} 
Conversion technique & $\begin{array}{c}\text { Proportion } \\
\text { of lands } \\
\text { converted }\end{array}$ & $\begin{array}{c}\text { Proportion } \\
\text { of samples } \\
\text { taken }\end{array}$ \\
\cline { 2 - 3 } Harvest only & --- (Percent) & ---- \\
Tractor scarify & 23 & 13 \\
Multiple spray & 55 & 53 \\
Slash and burn & 9 & 6 \\
Spray and burn & 5 & 8 \\
High-lead scarify & 7 & 1
\end{tabular}

Though complete sampling could not be achieved, 26 out of the 48 possible technique-zone combinations are represented by at least one sample project.

Both stocking and density measures may be used to compare relative success of conversion methods. Greatest reliance should be placed on estimates of stocking based on stocked quadrat surveys (100 plots/project). Density estimates based on measured distance to the nearest established conifer (25 sampling points) are less reliable. Because of the generally clumped tree distribution encountered on many conversion projects, density estimates are probably low in most instances (Batcheler 1971), and particularly so at low stocking levels. Subjective comparisons in the current survey can be based on stocking classes adopted some years ago for 1/250-acre plots (Reynolds et al. 1953). These classes are at least familiar to most foresters and land managers, if not agreed upon by all of them:

$\underline{\text { Stocking class } \quad \text { Stocking range }}$

(Percent)

\author{
Nonstocked \\ Poor stocking \\ Medium stocking \\ Good stocking
}

$$
\begin{array}{r}
0-9 \\
10-\quad 39 \\
40-\quad 69 \\
70-100
\end{array}
$$

Examples of good success were encountered in all six conversion techniques sampled (table 3). Likewise, successful conversions were examined in all but one of eight reclamation zones. The Oregon Coastal Plain was represented by only three individual projects which are probably not indicative of average success for the zone as a whole. Projects of poor success, on the other hand, were encountered only in association with tractor-scarify and multiple-spray conversions. The only exception was one harvest-only conversion that was marginal between poor and moderate stocking. Although less well represented, slash-and-burn, spray-andburn, and high-lead-scarify projects were all at least moderately successful and produced good stocking in 11 out of 15 instances.

Conversion success by all methods in terms of stocking obtained was 14 percent greater in Washington than in Oregon. This result reflects generally easier past conversion opportunities in Washington as well as inclusion of conversion projects from the North Cascade Foothills, where problems seem less difficult than those in other zones of either State. The trend was also heavily weighted by the relatively greater success of tractor-scarify conversions in Washington and may not suggest much real difference in ease of future conversion opportunities for either 
Table 3--Conifer stocking and density by conversion zone and technique for 99 projects in western Washington and Oregon-

\begin{tabular}{|c|c|c|c|c|c|c|}
\hline $\begin{array}{l}\text { Conversion } \\
\text { zone }\end{array}$ & Harvest & $\begin{array}{l}\text { Tractor } \\
\text { scarify }\end{array}$ & $\begin{array}{l}\text { Multiple } \\
\text { spray }\end{array}$ & $\begin{array}{l}\text { Slash } \\
\text { and } \\
\text { burn }\end{array}$ & $\begin{array}{l}\text { Spray } \\
\text { and } \\
\text { burn }\end{array}$ & $\begin{array}{l}\text { High-lead } \\
\text { scarify }\end{array}$ \\
\hline \multicolumn{7}{|l|}{ Washington: } \\
\hline $\begin{array}{l}\text { Washington } \\
\text { Coastal Plain }\end{array}$ & $\begin{array}{c}67 \\
(65-69) \\
270 \\
(2)\end{array}$ & $\begin{array}{c}80 \\
(63-95) \\
366 \\
(5)\end{array}$ & $\begin{array}{c}34 \\
-- \\
114 \\
(1)\end{array}$ & $\begin{array}{c}86 \\
-- \\
660 \\
(1)\end{array}$ & $\begin{array}{l}-- \\
-- \\
--\end{array}$ & $\begin{array}{l}-- \\
-- \\
--\end{array}$ \\
\hline $\begin{array}{l}\text { South Cascade } \\
\text { Foothills }\end{array}$ & $\begin{array}{c}67 \\
(55-79) \\
414 \\
(2)\end{array}$ & $\begin{array}{c}65 \\
(48-95) \\
279 \\
(11)\end{array}$ & $\begin{array}{c}38 \\
(6-69) \\
132 \\
(6)\end{array}$ & $\begin{array}{c}52 \\
-- \\
164 \\
(1)\end{array}$ & $\begin{array}{l}-- \\
-- \\
-- \\
--\end{array}$ & $\begin{array}{c}71 \\
-- \\
244 \\
(1)\end{array}$ \\
\hline $\begin{array}{l}\text { North Cascade } \\
\text { Foothills }\end{array}$ & $\begin{array}{l}-- \\
-- \\
-- \\
--\end{array}$ & $\begin{array}{c}78 \\
(27-93) \\
439 \\
(9)\end{array}$ & $\begin{array}{c}57 \\
-- \\
170 \\
(1)\end{array}$ & $\begin{array}{c}86 \\
(74-93) \\
532 \\
(3)\end{array}$ & $\begin{array}{c}86 \\
-- \\
522 \\
(1)\end{array}$ & $\begin{array}{l}-- \\
-- \\
-- \\
--\end{array}$ \\
\hline Willapa Hills & $\begin{array}{c}66 \\
(60-76) \\
359 \\
(3)\end{array}$ & $\begin{array}{c}82 \\
(65-92) \\
598 \\
(6)\end{array}$ & $\begin{array}{l}-- \\
-- \\
-- \\
--\end{array}$ & $\begin{array}{r}66 \\
-- \\
297 \\
(1)\end{array}$ & $\begin{array}{l}-- \\
-- \\
-- \\
--\end{array}$ & $\begin{array}{l}-- \\
-- \\
-- \\
--\end{array}$ \\
\hline \multicolumn{7}{|l|}{ Oregon: } \\
\hline $\begin{array}{l}\text { Oregon Coast } \\
\text { Ranges }\end{array}$ & $\begin{array}{r}69 \\
-- \\
366 \\
(1)\end{array}$ & $\begin{array}{c}62 \\
(28-83) \\
292 \\
(6)\end{array}$ & $\begin{array}{c}47 \\
(26-62) \\
126 \\
(11)\end{array}$ & $\begin{array}{l}-- \\
-- \\
-- \\
--\end{array}$ & $\begin{array}{c}73 \\
(64-89) \\
414 \\
(3)\end{array}$ & $\begin{array}{l}-- \\
-- \\
-- \\
--\end{array}$ \\
\hline Tillamook & $\begin{array}{c}46 \\
(39-57) \\
92 \\
(3)\end{array}$ & $\begin{array}{c}53 \\
(29-80) \\
144 \\
(5)\end{array}$ & $\begin{array}{l}-- \\
-- \\
--\end{array}$ & $\begin{array}{l}-- \\
-- \\
-- \\
--\end{array}$ & $\begin{array}{c}84 \\
(77-91) \\
506 \\
(4)\end{array}$ & $\begin{array}{l}-- \\
-- \\
-- \\
--\end{array}$ \\
\hline Nehalem Hills & $\begin{array}{c}58 \\
(44-73) \\
178 \\
(2)\end{array}$ & $\begin{array}{c}58 \\
(41-76) \\
163 \\
(7)\end{array}$ & $\begin{array}{l}-- \\
-- \\
-- \\
--\end{array}$ & $\begin{array}{l}-- \\
-- \\
-- \\
--\end{array}$ & $\begin{array}{l}-- \\
-- \\
--\end{array}$ & $\begin{array}{l}-- \\
-- \\
-- \\
--\end{array}$ \\
\hline $\begin{array}{l}\text { Oregon Coastal } \\
\text { Plain }\end{array}$ & $\begin{array}{l}-- \\
-- \\
--\end{array}$ & $\begin{array}{c}16 \\
(10-22) \\
16 \\
(3)\end{array}$ & $\begin{array}{l}-- \\
-- \\
-- \\
--\end{array}$ & $\begin{array}{l}-- \\
-- \\
--\end{array}$ & $\begin{array}{l}-- \\
-- \\
-- \\
--\end{array}$ & $\begin{array}{l}-- \\
-- \\
--\end{array}$ \\
\hline All & $\begin{array}{c}61 \\
(39-79) \\
265 \\
(13)\end{array}$ & $\begin{array}{c}65 \\
(10-95) \\
310 \\
(52)\end{array}$ & $\begin{array}{c}44 \\
(6-69) \\
130 \\
(19)\end{array}$ & $\begin{array}{c}77 \\
(52-93) \\
453 \\
(6)\end{array}$ & $\begin{array}{c}80 \\
(64-91) \\
424 \\
(8)\end{array}$ & $\begin{array}{r}71 \\
-- \\
244 \\
(1)\end{array}$ \\
\hline
\end{tabular}

1/ Within each data group statistics read from top to bottom: mean stocking, stocking range--in parentheses, mean density, and number of projects represented--in parentheses. Stocking is in percent based on $1001 / 250$ th-acre plots; density is in trees/acre based on 25 sampling points.

Oregon or Washington. On the basis of past experience, however, and general impressions formed in this survey, we predict that future hardwood conversions in Oregon will average more difficult and less successful than those in Washington. follows:

Impressions of success for each conversion technique are summarized as

Harvest only. Though the projects examined were moderately successful on the whole, none were outstanding; and most reflected intensive use of supplementary techniques such as release spraying and animal control after planting. In addition, 
most new stands were under heavy brush competition that was suppressing growth and reducing survival of conifers. Oregon's Tillamook conversion zone appeared least adaptable for successful use of harvesting with only incidental site preparation.

Tractor scarify. Tractor scarification produced the widest range of results in terms of conifer stocking (10 to 95 percent). This was the most common of al1 past methods and also the best represented in sampling. Success in Washington was generally high and consistently greater than that in Oregon ( 74 percent versus 52 percent). Average stocking ranged between 65 and 82 percent for four conversion zones in Washington; between 16 and 62 percent for four zones in Oregon. Stand densities in Washington were also notably higher than in Oregon. More aggressive brush and possibly greater problems with tree-damaging animals in Oregon may account for most of these differences.

Muztiple spray. Use of chemical sprays alone without scarification or burning was overall the least successful of techniques sampled. Stocking levels resulting from this practice averaged between poor and medium (40 percent) in Washington, and only slightly better in Oregon (47 percent). Medium stocking, however, was obtained on 14 out of 19 projects for both States combined. A complex of live and dead brush in the understory combined with both live and dead hardwoods in the overstory to produce conditions inimical to planted conifers. Growth and survival of conifer seedlings were hindered by competition for nutrients and moisture, by excessive shading, by physical obstruction of fallen dead materials, and, to some extent, by animal damage.

Stash and bum. Though examples of this technique were not examined in Oregon, its use in Washington was mostly successful. Based on six projects, stocking was medium on two and good to excellent on the remaining four. In one instance, slash and burn was successfully applied to an attempted multiple-spray conversion that had previously failed. The technique requires considerable investment in materials and labor; but it avoids most use of expensive mechanical equipment such as employed in scarification.

Spray and bum. This technique is used shortly after harvest of merchantable hardwoods to reduce complexes of slash and generally low brush. Seven out of eight conversions were located in Oregon, and all were at least moderately successful. Six resulted in good stocking, and two provided high levels of medium stocking. Based on four examples, the technique worked especially well in the Tillamook zone.

High-lead scarify. Only one example of this technique was sampled. Located in Washington's South Cascade Foothills, it provided good stocking of conifers able to compete with developing brush. The method is expensive and will probably require follow-up with herbicide or other treatments to insure survival and maintain dominance of conifers on most areas.

Relationship of conversion success to variables other than the techniques applied was summarized for site index, understory, aspect, and slope.

No consistent trend appeared to be associated with site index. Although more intensive effort was usually devoted to converting higher sites, average stocking was only slightly greater and may well have been offset by generally more difficult conversion opportunities: 


\begin{tabular}{|c|c|c|}
\hline Site index & Projects & Mean stocking \\
\hline & (Number) & (Percent) \\
\hline 130 & 3 & 60 \\
\hline 140 & 17 & 63 \\
\hline 150 & 8 & 56 \\
\hline 160 & 23 & 67 \\
\hline 170 & 22 & 55 \\
\hline 180 & 13 & 65 \\
\hline $190+$ & 13 & 70 \\
\hline
\end{tabular}

Understory communities dominated by sword-fern and vine maple regenerated less successfully than salmonberry or salal communities. This trend was apparent in both Washington and Oregon and suggests real differences in ease of conversion for different plant communities:

\begin{tabular}{lcc}
\multicolumn{1}{c}{ Understory } & Projects & Mean stocking \\
(Number) & & \\
Washington: & & 62 \\
Sword-fern & 14 & 77 \\
Salmonberry & 18 & 63 \\
Vine maple & 17 & 77 \\
Salal & 5 & \\
Oregon: & 7 & 54 \\
Sword-fern & 27 & 56 \\
Salmonberry & 8 & 51 \\
Vine maple & 3 & 64 \\
Salal & & \\
Washington and Oregon: & 21 & 59 \\
Sword-fern & 45 & 65 \\
Salmonberry & 25 & 59 \\
Vine maple & 8 & 72 \\
Salal & &
\end{tabular}

The above differences in conversion success are obviously confounded by other variables of site, technique, and sample size that make their interpretation difficult. Furthermore, no obvious correlation between conversion technique and understory could be detected. Multiple-spray conversions averaged least successful in the sword-fern dominated understory type (table 4).

Though differences were erratic, there are some indications that southerly and westerly aspects were converted more successfully than easterly and northerly aspects:

$\begin{array}{ccc}\text { Aspect } & \text { Projects } & \text { Mean stocking } \\ \text { N } & \text { (Number) } & \\ \text { NE } & 15 & 61 \\ \text { E } & 4 & 48 \\ \text { SE } & 6 & 51 \\ \text { S } & 9 & 70 \\ \text { SW } & 27 & 60 \\ \text { W } & 11 & 71 \\ \text { NW } & 11 & 74 \\ \text { Level or mixed } & 6 & 67 \\ \end{array}$


Table 4--Conifer stocking by understory and conversion technique for 99 projects in westerm Washington and Oregon -

\begin{tabular}{l|c|c|c|c|c|c}
\hline Understory & Harvest & $\begin{array}{c}\text { Tractor } \\
\text { scarify }\end{array}$ & $\begin{array}{c}\text { Multiple } \\
\text { spray }\end{array}$ & $\begin{array}{c}\text { Slash } \\
\text { and } \\
\text { burn }\end{array}$ & $\begin{array}{c}\text { Spray } \\
\text { and } \\
\text { burn }\end{array}$ & $\begin{array}{c}\text { High-lead } \\
\text { scarify }\end{array}$ \\
\hline Sword-fern & $67(2)$ & $68(8)$ & $37(7)$ & $74(4)$ & -- & -- \\
Salmonberry & $60(7)$ & $66(22)$ & $47(7)$ & $91(1)$ & $79(7)$ & $71(1)$ \\
Vine maple & $58(4)$ & $60(14)$ & $48(5)$ & $74(1)$ & $86(1)$ & -- \\
Salal & -- & $72(8)$ & -- & -- & - & -- \\
\hline
\end{tabular}

1/ Stocking is in percent based on $1001 / 250$ th-acre plots; data in parentheses are number of projects represented.

Although this trend, if real, runs counter to the normally expected tendency for south exposures to provide difficult natural regeneration opportunities (Bever 1954, Lavender et al. 1956), there is at least no indication that such was the case among the conversion projects sampled. Both Shaw (1953) and Stewart (1966) found that south slopes regenerated more successfully than other aspects following artificial seeding. A common association between north slopes and sword-fern communities may also suggest problems in type conversion that differ from those following conventional conifer harvest.

Not unexpectedly, a trend toward a decrease in conversion success was associated with an increase in steepness of slope:

\begin{tabular}{|c|c|c|}
\hline Slope & Projects & Mean stocking \\
\hline (Percent) & (Number) & (Percent) \\
\hline 0 and 5 & 22 & 70 \\
\hline 10 and 15 & 20 & 69 \\
\hline 20 and 25 & 18 & 61 \\
\hline 30 and 35 & 16 & 62 \\
\hline 40 and 45 & 7 & 57 \\
\hline 50 and 55 & 7 & 49 \\
\hline 60 and 65 & 5 & 46 \\
\hline $70+$ & 5 & 46 \\
\hline
\end{tabular}

Marginally good stocking was obtained on level to gentle terrain where more intensive methods, such as tractor scarification, could be applied. Success generally fell to low levels of medium stocking on slopes in excess of 45 percent.

In response to general questions regarding factors that limited regeneration success on specific hardwood conversions, a majority of managers indicated that competing vegetation and animal damage were of prime importance:

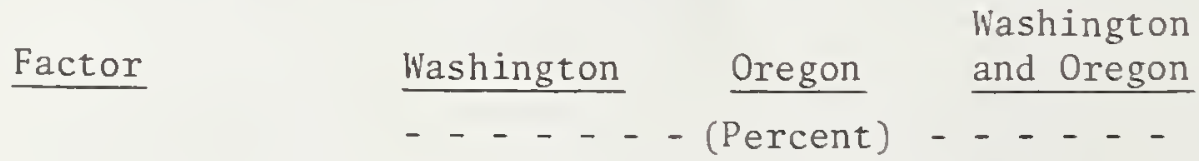

Weather

Competing vegetation

Animal damage

Poor planting stock

Other

7
41
52
7
6

5

$5 \overline{3}$

55

15

5 
A common association between competition and damage factors suggests that densely vegetated sites provided good habitat for damaging animals. Since most conversion techniques probably improve habitat for such animals, the two problems are closely intertwined (Dimock 1974).

\section{CONVERSION COSTS}

On some recent projects, not all costs of conifer establishment have yet occurred; and this fact should be considered in interpreting cost data. Since 1972, 27 percent of the sampled projects have been planted or replanted. Hence, many of these conversions will probably require further silvicultural treatment to insure their success. In one extreme case a multiple-spray project has already cost $\$ 212$ per acre with only 6 -percent stocking success resulting. Another $\$ 200-$ $\$ 300$ per-acre outlay for retreatment over the next few years is anticipated, but not included in our cost data. Some older projects, on the other hand, include all or nearly all expenditures needed for successful stand establishment.

Average total costs per acre ranged from $\$ 39$ to $\$ 505$ (table 5). In general, the cost variation within each technique-zone conversion class is so large that few concrete conclusions can be drawn. Mean per-acre costs for each conversion technique suggest that harvest only was least expensive (\$103), followed by tractor scarify $(\$ 140)$, multiple spray $(\$ 149)$, slash and burn $(\$ 235)$, and spray and burn $(\$ 269)$. However, in terms of cost per established conifer, both slash-and-burn and spray-and-burn techniques compared favorably with harvest and tractor-scarify methods--despite substantially higher per-acre costs for the former. In contrast, though multiple-spray conversions were only moderately expensive per acre, costs per established conifer were high, averaging over $\$ 1$. Cost of high-lead scarification $(\$ 210)$, represented by only one sample, was probably low based on our experience.

Mean expenditures for conversion were quite similar between Washington and Oregon ( $\$ 153$ and $\$ 155$ per acre). Costs for public conversion projects, however, averaged $\$ 223$ compared to $\$ 139$ for projects in the private sector. The $\$ 84$ difference likely reflects costly environmental constraints associated with more recent conversions on public lands, in addition to possible selection bias and probable sampling error. In summary, an average conversion cost of $\$ 154$ per acre suggests that brushland reclamation is seldom cheap. Moreover, since actual tree planting costs averaged on $1 y$ about half the total conversion outlay $(\$ 78)$, the continuing need for intensive and improved site preparation treatments seems abundantly clear in high-site hardwood conversion. 
Table 5--Conversion costs by zone and technique expressed in 1975 dollars per acre for 99 projects in western Washington and Oregon 1/

\begin{tabular}{|c|c|c|c|c|c|c|}
\hline $\begin{array}{l}\text { Conversion } \\
\text { zone }\end{array}$ & Harvest & $\begin{array}{l}\text { Tractor } \\
\text { scarify }\end{array}$ & $\begin{array}{l}\text { Multiple } \\
\text { spray }\end{array}$ & $\begin{array}{l}\text { Slash } \\
\text { and } \\
\text { burn }\end{array}$ & $\begin{array}{l}\text { Spray } \\
\text { and } \\
\text { burn }\end{array}$ & $\begin{array}{l}\text { High-lead } \\
\text { scarify }\end{array}$ \\
\hline \multicolumn{7}{|l|}{ Washington: } \\
\hline $\begin{array}{l}\text { Washington } \\
\text { Coastal Plain }\end{array}$ & $\begin{array}{c}96 \\
(89-102) \\
0.35 \\
(2)\end{array}$ & $\begin{array}{c}101 \\
(54-204) \\
0.26 \\
(5)\end{array}$ & $\begin{array}{l}133 \\
-- \\
(1)^{17}\end{array}$ & $\begin{array}{l}254 \\
-- \\
0.38 \\
(1)^{38}\end{array}$ & $\begin{array}{l}-- \\
-- \\
-- \\
--\end{array}$ & $\begin{array}{l}-- \\
-- \\
-- \\
--\end{array}$ \\
\hline $\begin{array}{l}\text { South Cascade } \\
\text { Foothills }\end{array}$ & $\begin{array}{c}102 \\
(58-174) \\
0.24 \\
(2)\end{array}$ & $\begin{array}{c}132 \\
(45-275) \\
0.47 \\
(11)\end{array}$ & $\begin{array}{c}158 \\
(117-212) \\
1.20 \\
(6)\end{array}$ & $\frac{170}{--}(1)^{04}$ & $\begin{array}{l}-- \\
-- \\
--\end{array}$ & $\begin{array}{l}210 \\
-- \\
0.86 \\
(1)\end{array}$ \\
\hline $\begin{array}{l}\text { North Cascade } \\
\text { Foothills }\end{array}$ & $\begin{array}{l}-- \\
-- \\
-- \\
--\end{array}$ & $\begin{array}{c}153 \\
(122-173) \\
0.34 \\
(9)\end{array}$ & $\begin{array}{l}153 \\
-- \\
0.90 \\
(1)\end{array}$ & $\begin{array}{c}229 \\
(183-257) \\
0.43 \\
(3)\end{array}$ & $\begin{array}{l}176 \\
-- \\
0.34 \\
(1)\end{array}$ & $\begin{array}{l}-- \\
-- \\
--\end{array}$ \\
\hline Willapa Hills & $\begin{array}{c}150 \\
(66-197) \\
0.42 \\
(3)\end{array}$ & $\begin{array}{c}174 \\
(70-291) \\
0.29 \\
(6)\end{array}$ & $\begin{array}{l}-- \\
-- \\
-- \\
--\end{array}$ & $\begin{array}{l}300 \\
-- \\
1.01\end{array}$ & $\begin{array}{l}-- \\
-- \\
--\end{array}$ & $\begin{array}{l}-- \\
-- \\
--\end{array}$ \\
\hline \multicolumn{7}{|l|}{ Oregon: } \\
\hline $\begin{array}{l}\text { Oregon Coast } \\
\text { Range }\end{array}$ & $\begin{array}{l}148 \\
-- \\
0.40 \\
(1)\end{array}$ & $\begin{array}{c}185 \\
(94-282) \\
0.63 \\
(6)\end{array}$ & $\begin{array}{c}145 \\
(39-351) \\
1.15 \\
(11)^{15}\end{array}$ & $\begin{array}{l}-- \\
-- \\
--\end{array}$ & $\begin{array}{c}330 \\
(193-505) \\
0.80 \\
(3)\end{array}$ & $\begin{array}{l}-- \\
-- \\
-- \\
--\end{array}$ \\
\hline Tillamook & $\begin{array}{c}65 \\
(41-89) \\
0.70 \\
(3)\end{array}$ & $\begin{array}{c}184 \\
(77-487) \\
1.28 \\
(5)\end{array}$ & $\begin{array}{l}-- \\
-- \\
--\end{array}$ & $\begin{array}{l}-- \\
-- \\
--\end{array}$ & $\begin{array}{c}246 \\
(135-389) \\
0.49 \\
(4)\end{array}$ & $\begin{array}{l}-- \\
-- \\
--\end{array}$ \\
\hline Nehalem Hills & $\begin{array}{c}78 \\
(75-81) \\
0.43 \\
(2)\end{array}$ & $\begin{array}{c}73 \\
(63-91) \\
0.45 \\
(7)\end{array}$ & $\begin{array}{l}-- \\
-- \\
--\end{array}$ & $\begin{array}{l}-- \\
-- \\
--\end{array}$ & $\begin{array}{l}-- \\
-- \\
--\end{array}$ & $\begin{array}{l}-- \\
-- \\
--\end{array}$ \\
\hline $\begin{array}{l}\text { Oregon Coastal } \\
\text { Plain }\end{array}$ & $\begin{array}{l}-- \\
-- \\
--\end{array}$ & $\begin{array}{c}112 \\
(97-120) \\
7.17 \\
(3)\end{array}$ & $\begin{array}{l}-- \\
-- \\
--\end{array}$ & $\begin{array}{l}-- \\
-- \\
--\end{array}$ & $\begin{array}{l}-- \\
-- \\
--\end{array}$ & $\begin{array}{l}-- \\
-- \\
--\end{array}$ \\
\hline A11 & $\begin{array}{c}103 \\
(41-197) \\
0.39 \\
(13)\end{array}$ & $\begin{array}{c}140 \\
(45-487) \\
0.45 \\
(52)^{4}\end{array}$ & $\begin{array}{c}149 \\
(39-351) \\
1.15 \\
(19)\end{array}$ & $\begin{array}{c}235 \\
(170-300) \\
0.52 \\
(6)\end{array}$ & $\begin{array}{c}269 \\
(135-505) \\
0.57 \\
(8)\end{array}$ & $\begin{array}{l}210 \\
-- \\
0.86 \\
(1)\end{array}$ \\
\hline
\end{tabular}

1/ Within each data group, statistics read from top to bottom: mean cost, cost range--in parentheses, cost per established conifer, and number of projects represented--in parentheses.

\section{Conclusions}

More than 100,000 acres of brush and $3 / 4$ million acres of brush-hardwood mixtures--almost all potentially convertible to conifers--presently occur on over 6.1 million acres of forest lands sampled in this survey. If one assumes that these lands typify forest ownerships in the Coast Ranges and western Cascade Range foothills of Washington and Oregon, the task of converting high-site brush and hardwoods to more valuable conifers for the above region as a whole will exceed by 3 times the management projections summarized here. Much has been done already. Over 200,000 acres on the ownerships surveyed have now been reclaimed. However, more than 3 times that amount are scheduled for future conversion from hardwoods to conifers. 
To date, managers have concentrated their reclamation efforts on the easiest and most accessible conversion opportunities. Generally more difficult and remote opportunities remain. Not all conversion techniques proven in the past to be successful on gentle terrain will be adaptable to steep ground. Hence, there is an urgent need not only to refine existing methods but also to devise new ones. As at present, various techniques will be required to fit different circumstances; and no single method will foreseeably apply to all or even most conditions. Improved guidelines for prescribing techniques that provide the best balance between success and cost in given situations are also needed.

The harvest-only method lends itself less readily to current conditions than any other method examined. Unless market conditions and utilization standards for hardwoods (chiefly red alder) improve quite radically, this situation is likely to persist. The technique is often effective only when accompanied by intensive, supplemental measures such as spraying, burning, and animal control. Moreover, it has immediate application only to hardwood stands of harvestable age. In past practice, the harvest-only method was most applicable to the easiest conversion opportunities that presented little slash-disposal or brush-threat problems.

Tractor scarification will continue to be useful on gentle ground with slopes not exceeding 30 percent. Less terrain of this kind will be available in future conversion opportunities, and use of tractor scarification will be increasingly limited. Tractors used in "yo-yo" fashion--one tractor lowering another downslope, then back up with its winch--can extend this method to steeper slopes, but the technique is expensive (Gratkowski et al. 1973) and results in site degradation. Likewise, scarification by high-lead techniques remains quite costly, but may have good possibilities for future use if efficiency can be improved. All scarification projects observed in this survey showed that partial scarification was generally less successful than more complete mechanical disruption for attaining good conifer stocking within a short space of time.

Multiple-spray conversion techniques generally fell short of providing desired levels of conifer stocking. Only 3 out of 19 projects examined yielded even high levels of medium stocking (60-69 percent). These results suggest that additional refinements of this method are needed to improve its success and consistency on high sites. Possibly development of more effective and broader spectrum herbicides will help to achieve better conifer stocking. Methods developed to reduce the complex of live and dead brush even further than normally possible with sprays alone are probably needed to provide a favorable seedling environment.

Combinations of chemicals and fire, as in slash-and-burn and spray-and-burn techniques, were most consistently successful in achieving conversion with high levels of conifer stocking. These methods tentatively appear to have best potential for both future application and further refinement. Nevertheless, environmental constraints may limit opportunities for their use. Hence, if viable options are to remain open to forest managers for converting low-value brush/ hardwood stands to highly productive coniferous forests, continuing technological advances will be vital. 


\section{Literature Cited}

Batcheler, C. L.

1971. Estimation of density from a sample of joint point and nearest-neighbor distances. Ecology 52:703-709, illus.

Bever, Dale N.

1954. Evaluation of factors affecting natural reproduction of forest trees in central western Oregon. Oreg. State Board For. Res. Bull. No. 3, 49 p., illus.

Dimock, Edward J., II.

1974. Animal populations and damage. In Environmental effects of forest residues management in the Pacific Northwest, a state-of-knowledge compendium. USDA For. Serv. Gen. Tech. Rep. PNW-24, p. 0-1 to 0-28. Pac. Northwest For. and Range Exp. Stn., Portland, Oreg.

Franklin, Jerry F., and C. T. Dyrness.

1973. Natural vegetation of Oregon and Washington. USDA For. Serv. Gen. Tech. Rep. PNW-8, 417 p., illus. Pac. Northwest For. and Range Exp. Stn., Portland, Oreg.

Gratkowski, H., D. Hopkins, and P. Lauterbach.

1973. Rehabilitation of forest land--the Pacific Coast and northern Rocky Mountain region. J. For. $71: 138-143$, illus.

Lavender, Denis P., Morris H. Bergman, and Lyle D. Calvin. 1956. Natural regeneration on staggered settings. Oreg. State Board For. Res. Bull. No. 10, 36 p., illus.

Reynolds, Charles, Nelson Jeffers, Vincent Bousquet, and Roy Stier.

1953. Reforestation surveys. Chapter 7. In Reports of the Pacific Northwest Seeding and Planting Committee on Various Recommended Reforestation Practices and Techniques. West. For. and Conserv. Assoc., Portland, Oreg. p. 61-69, illus.

Shaw, Elmer $W$.

1953. Effects of tetramine used for rodent control in direct seeding of Douglas-fir. USDA For. Serv. Pac. Northwest For. and Range Exp. Stn. Res. Note No. $89,7 \mathrm{p}$.

Stewart, Ronald.

1966. A study of Douglas-fir aerial seeding. State Wash. Dep. Nat. Resour., For. Land Manage. Bul1. No. 4, 25 p., illus. 


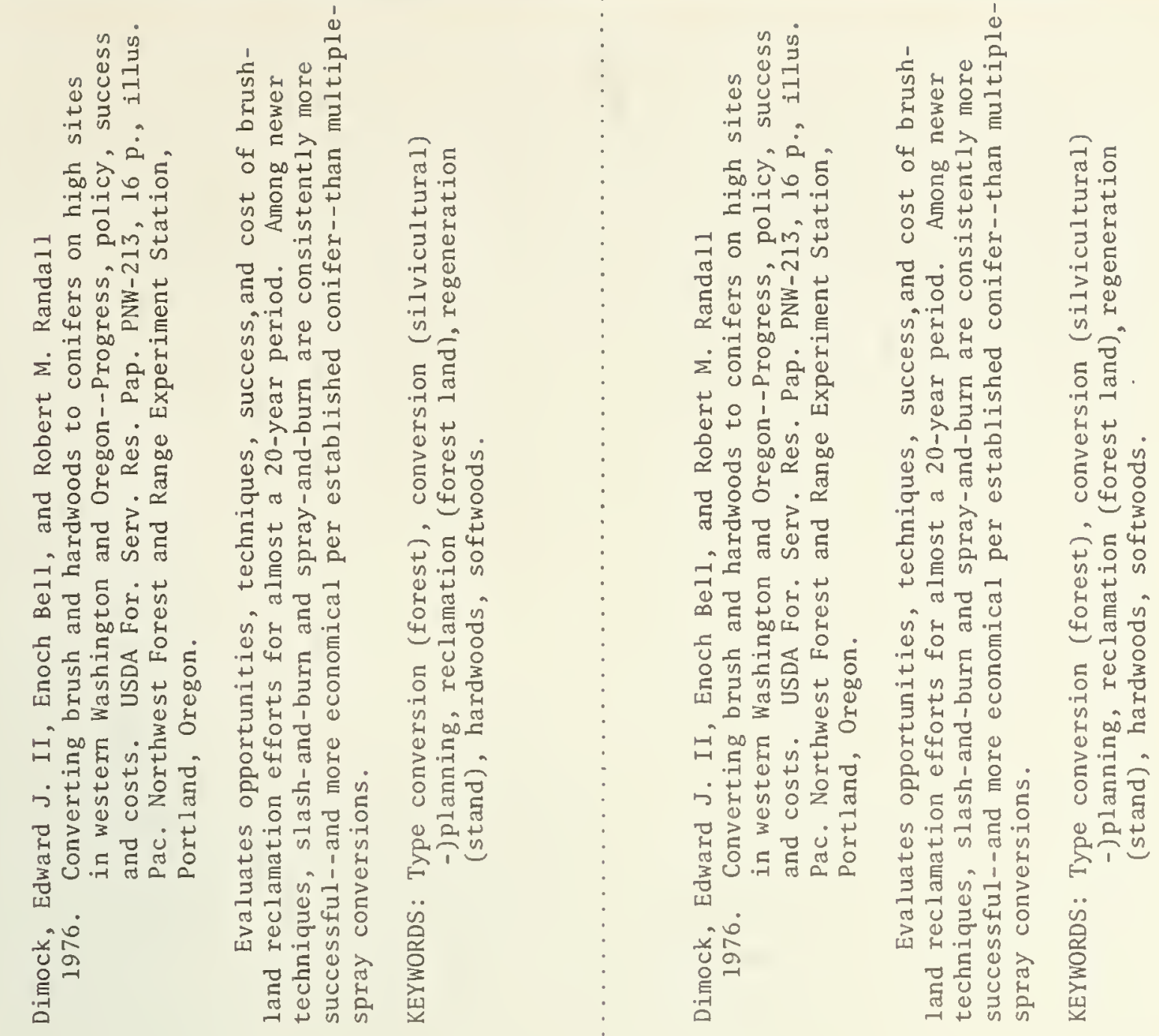

\begin{tabular}{|c|c|c|c|c|c|}
\hline 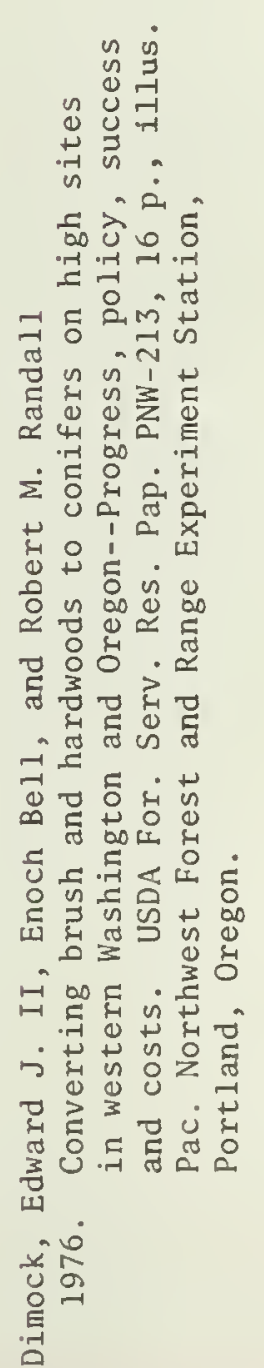 & 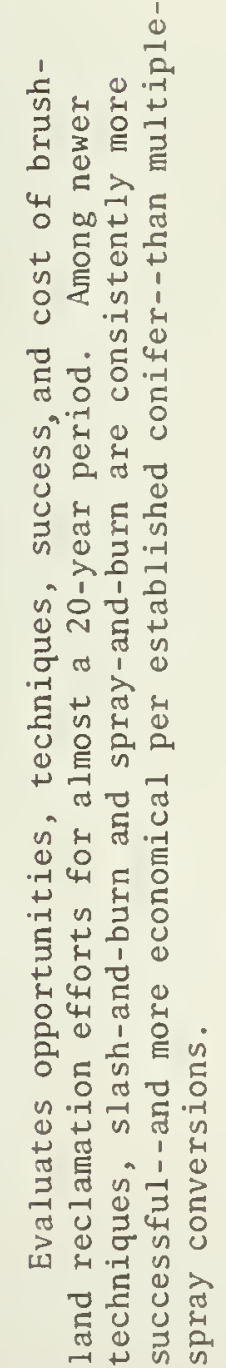 & 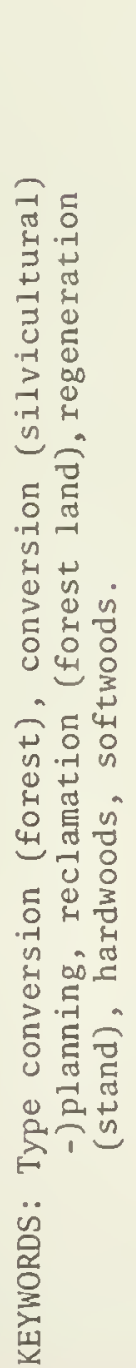 & 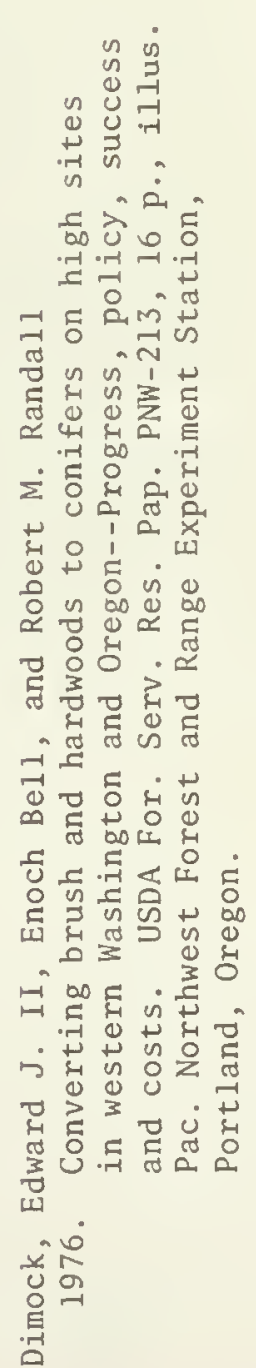 & 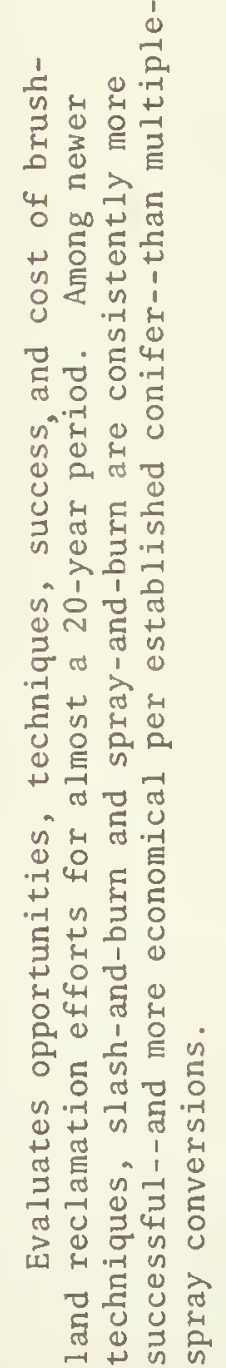 & 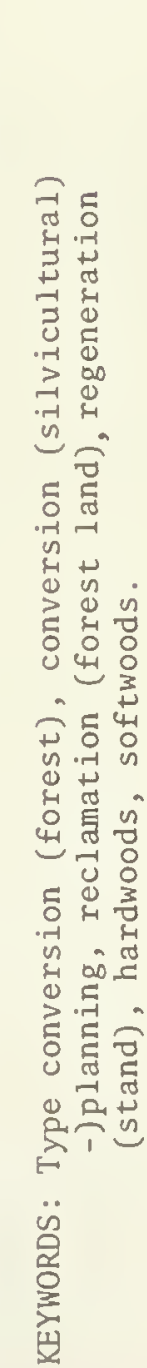 \\
\hline
\end{tabular}




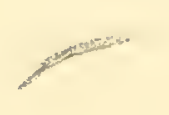


The mission of the PACIFIC NORTHWEST FOREST AND RANGE EXPERIMENT STATION is to provide the knowledge, technology, and alternatives for present and future protection, management, and use of forest, range, and related environments.

Within this overall mission, the Station conducts and stimulates research to facilitate and to accelerate progress toward the following goals:

1. Providing safe and efficient technology for inventory, protection, and use of resources.

2. Developing and evaluating alternative methods and levels of resource management.

3. Achieving optimum sustained resource productivity consistent with maintaining a high quality forest environment.

The area of research encompasses Oregon, Washington, Alaska, and, in some cases, California, Hawaii, the Western States, and the Nation. Results of the research are made available promptly. Project headquarters are at:

Fairbanks, Alaska

Juneau, Alaska

Bend, Oregon

Corvallis, Oregon

La Grande, Oregon
Portland, Oregon

Olympia, Washington

Seattle, Washington

Wenatchee, Washington

Mailing address: Pacific Northwest Forest and Range Experiment Station

P.O. Box 3141

Portland, Oregon 97208

GPO $997-498$ 


\section{0}

The FOREST SERVICE of the U.S. Department of Agriculture is dedicated to the principle of multiple use management of the Nation's forest resources for sustained yields of wood water forage, wild life, and recreation. Through forestry research, cooperation with the States and private forest owners, and management of the National Forests and National Grasslands, it strives - as directed by Congress - to provide increasingly greater service to a growing Nation.

The U.S. Department of Agriculture is an Equal Opportunity Employer. Applicants for all Department-programs wilt be givén equal consideration without regard to race, color, sex or national origin 